\title{
Codes' Switching as Strategic Resource of an Addresser in Mass Media Discourse
}

\author{
Olga Verbitskaya $^{1}$, Ekaterina Lesnikovskaya ${ }^{1}$, and Natalia Panchenko ${ }^{2}$ \\ ${ }^{1}$ Department of Asian-Pacific Area Studies, Irkutsk State University (Institute of Philology, Foreign Languages, and Media- \\ communication), Irkutsk, Russia \\ ${ }^{2}$ Department of Foreign Languages, Irkutsk State University (Institute of Philology, Foreign Languages, and Media-communication), \\ Irkutsk, Russia
}

\begin{abstract}
The article considers "codes' switching" as a special linguistic and socio-cultural competence. The authors provide an analysis of an addresser's strategic use of a marked code as a specific tool of an individual aim-achieving. Code-switching is considered to be a supplementary resource of a communicant, a resource used to reach some pragmatic aims of communication.
\end{abstract}

\section{Introduction}

Since the second half of the XX century, both linguists and sociologists have shown a deep interest in codeswitching. Codes' switching or code-switching is usually defined as switching from one language to another during an act of communication. For the purpose of this article, we define code-switching in a broader sense: by the code we mean not only a different language, but also a different pattern, a different genre accent within the same language. The driving force behind the scholars' interest in code switching is considered by many researchers to be globalization and integration processes that lead to increasing the number of language contacts in the world [1].

Code-switching is closely tied to the phenomena of bilingualism and multilingualism, which is especially well illustrated by the classic definitions of these phenomena. For instance, E. Haugen points out that code-switching takes place when "...a bilingual introduces a completely unassimilated word from another language into his speech" [2]. C. Nilep argues that for the purposes of socio-cultural analysis it is advisable to define code-switching as changing the form of communication which signals changing the context [3].

The notion of code-switching has gone through significant transformation. C. Alvarez Caccamo links this fact to the conceptual meaningfulness of the notion comparing it to the one of such a popular notion as speech act [4]. Accordingly, the approach to studying the phenomenon has changed from seeing it as a specific feature of a bilingual to understanding it as a means of constructing the speaker's identity. The latter has been supported by the opinion that code-switching is also caused be extralinguistic factors such as psychological or socially conditioned ones. In spite of code-switching being, first of all, a linguistic phenomenon, research circles have shown interest in the associated social functions and contexts as well [4]. The article covers the social conditionality of code-switching and the pragmatic functions it has. In particular, we will review code-switching as an advantage, a special socio-cultural competence of the speaker (differentiated from knowing one more language), as a strategic resource of the speaker.

\section{Results and Discussion}

The importance of codes' switching in the study of linguistic and social phenomena is typically analyzed in terms of the linguistic constraints that determine the form taken by code switching or its structural patterns, but evidently the sociolinguistic functions, which determine when, with whom, and why code switching takes place pays its tribute. The most significant issue here is the acceptability of switching which, in its turn, identifies the successfulness or unsuccessfulness of an act of communication.

The social meaningfulness of the fact of codeswitching is manifested at two levels. Firstly, the very markedness (conscious choice) of the "Southern" accent makes it socially meaningful in the given communicative act. Secondly, the situation in which code-switching was used (an election speech of a famous politician on the anniversary of a nation-wide historical event) increases the social meaningfulness of the code-switching significantly. These specifications pose even higher risks of inappropriate code-switching for strategic goals.

Let us consider an example of how a politician (Hilary Clinton) has used code-switching in the course of her election campaign (the speech took place on March, 4, 2007 in Selma, Alabama). Senator of New York State

* Corresponding author: overbitskaia@gmail.com 
and a presidential candidate Hillary Clinton said a few phrases specifically using an accent common in southern states of the USA (Southern American English). That phonetic switch, not typical of her everyday speech, was obviously used to create a positive image of a person southerners could identify themselves with. The speech in Selma was broadcast on the American television (Fox News Channel, for example) and became well known to the public. At the same time, the result of such pragmatic use of code-switching was ambiguous. The fact became widely discussed - while TV-channels presented the situation in a neutral way, Internet-discussions showed mainly negative reactions to $\mathrm{H}$. Clinton's speech. In the discussions, common phrases are those about "fake" Southern accent; this part of the speech is often described with such words as "insulting", "offensive", "patronizing", and is seen as a "plain political stunt" [portal Youtube.com, Internet-forum Bodybuilding.com]. In his article eloquently titled "Insulting Blacks", journalist W.E. Williams questions the reasonability of $\mathrm{H}$. Clinton's use of AfricanAmerican dialect in speeches before African-American audience [5].

Code-switching for strategic goals is more and more widely used in marketing as well. A good illustration of this are commercials on the American television that use code-switching from English to Spanish. Hispanics are the fastest growing American community as well as the youngest ethnic group in the USA, thus a desirable target for marketing campaigns. For instance, code-switching is used in McDonalds commercials ("House Divided", 2014) and Taco Bell (Viva Young Super Bowl Commercial, 2013). Notably, these commercials were broadcast on federal (English-speaking) TV-channels although there is a wide range of Spanish-speaking TVchannels in the USA. In this connection, S. Poplack makes an interesting observation basing on the survey of Puerto Ricans in New York. She points out that codeswitching from English to Spanish (and back) is so much integrated into the language life of the community that the code-switching in itself is a special mode of interaction [6].

Moreover, code-switching in the media news discourse can be seen as the creation of additional news. In a grueling pursuit of news, journalists are constantly looking for some original ways of its presentation. They resort to manipulative strategies which are realized through numerous linguistic devices (means) / figures of speech / rhetorical structures / tropes leading to the transformation of the genre of news. The intentional character of their incorporation into the text qualifies the journalist as a creative person - a member of the tropological elite, who owns "the standards of cultural excellence" for creating complex types of discourse.

As an example, let us consider the heading of the article "Dummkopf (Germans have long been proud of their schooling. Too long, it seems)" (Economist, Feb. $15,2011)$. The strategic goals of the journalist to inform and influence are achieved by replacing of the reduced lexical unit in English with its equivalent in German. This formal duality is supplemented and accentuated by the usual antonymic opposition typical of irony (long been proud-too long, it seems).

One more thought-provoking example of codeswitching is actualized in the article under the heading "Pardners, if not comrades" (Times, Oct. 21, 2012). The news message in it concerns the forthcoming visit of the Chinese leader to the United States. The writer has already demonstrated his intellect in the title at full length, citing in his wrong, "Chinese" version the word partners (pardners), as well as the word comrades inherent in the speech of the Chinese communists. With the help of conjunction if not the comparison of these words (pardners - comrades) creates an implicit meaning that the leaders of these countries are unlikely to be friends. Thus, the creation of additional news is only possible for the representatives of the intellectual tropological elite. It is worth noting that appealing to highly educated and cultivated readers the journalist is fully aware that incorporating of foreign words becomes clear without translation.

Codes' switching is a compensation for a linguistic deficit in a communication; quite often it's a linguistic behavior which is purpose-motivated and contextinfluenced. It may occur in various communities and social groups and is defined by different social situations.

The usage of slang expressions is also a manifestation of code switching in daily life. Communicants use expressions that are specific to a specific field of activity. For some, it's a necessary means of communication and the only (or the easiest) way to name an object or a process in one word; for the others, it's a secret code basing on which they recognize a person of the same sphere. An approach to switch codes via the usage of some specific sphere is also an effective means to influence an addressee. People who work in a professional environment are gradually getting used to communication which includes slang, and it is imperceptible for them to focus their attention on anchoring slang phrases.

Sometimes people use slang phrases as code switching which entered into everyday communication from the sphere of business without realizing it. For example, 'take it offline', a commonly used phrase, means some communication outside of the normal channel; used in the article "When Should I Take an Interaction Offline?" (NYT) in context as follows: "There are many different situations that a business will encounter when engaging with customers online. Although it is beneficial to post a public response, there are sometimes negative instances where it is better to take a conversation offline, or make it private.", it switches the code of communication from a serious one into a lightly humorous.

In mass media discourse there is as well an interesting linguistic phenomenon with the word 'deck' the meaning of which in business slang is the "Powerpoint slides used for presentations". Slide deck refers to the old presentation technology where there is photo transparency slide. A set of them are placed in a deck like a deck of cards. So, in the article "The 7 Elements Investors Look for in Your Funding Pitch" 
(NYT) this word used in the following context: "There is no such thing as a "perfect" pitch deck. Pitch decks are continually refined to optimize for the immediate audience to whom the deck is being presented." usage creates intentionally an ironic attitude of an addressee towards the information of the article.

'Sunsetting' in a corporate language means phasing something out or stopping to do something. Products and services are often sunsetted when they are no longer sufficiently profitable or when a company decides to change its focus. In this case, sunsetting usually means that the product is no longer supported. For instance, this word presented in the article "EBay just killed off its same-day delivery service": "EBay will also be sunsetting some of its apps, eBay Motors, eBay Fashion, and eBay Valet, as it looks to focus customers' attention on its flagship app."(NYT), changes the degree of compensational ability of an addressee to perceive the information of the article non-metaphorically.

One more example is 'brick-and-mortar', which is a traditional street-side business that deals with its customers face-to-face in an office or a store that the business owns or rents. The name is a metonym derived from the traditional building materials associated with physical buildings: bricks- and-mortar .The term was originally used by 19 century novelist Charles Dickens in the book "Little Dorrit". In the article "How brickand-mortar stores can survive the Internet craze?" (NYT) there is the following context: "Traditional brick-andmortar stores may be struggling due to the meteoric rise of online shopping, but it doesn't mean they're losing out on those sales-they're just moving to their website." The intentional usage of this idiom influences the information perception on the social level: it presents the addressant of the article as an ordinary suburban community resident and shortens the distance between him and an addressee.

The use of code-switching in political activity and marketing is an example of the strategic choice of the language of the code by the speaker (whether from two or more languages or within the same language). The language choice of the addresser in the above-noted cases is marked, conscious, and rational [7]. In this context, the use of marked language choice is a strategic decision of the speaker who pursues a specific goal. In the example with the politician, the strategic goal was to increase popularity among voters; in the case of TV commercials the goal was to draw attention of Hispanics who represent a significant share of TV audience. The above-noted examples confirm C. Myers-Scotton's idea that when code-switching, you as a speaker “...choose the form of your controversial contribution such that it symbolizes the set of rights and obligations which you wish to be in force between speaker and addressee..." [7]. Myers-Scotton's theory (theory of markedness) explains the negative reaction to $\mathrm{H}$. Clinton's use of "Southern" accent by the violation of certain obligations before the addressee (the audience, potential voters). A part of the audience, using their communicative competences, regarded H. Clinton's marked choice of the style as an inappropriate (patronizing, unreasonable) stroke of policy. According to C. Myers-Scotton, native speakers have a "natural theory of markedness" and are able to differentiate a rational use of a code from a natural one automatically [7].

Interesting examples of code switching may be found in Mass media speeches of the $45^{\text {th }}$ president of the United States Donald J. Trump. His speeches and actions towards POCs, women, immigrants, welfare systems and healthcare are forming a completely new mentality and culture, a new idea of "American Identity", i.e. the autostereotypical understanding of the Americans of who and what they are. So, Donald Trump kicked off his election company with radical statements towards Mexican, South American and Middle Eastern immigrants: "When Mexico sends its people, they're not sending their best... They're sending people, that have lots of problems and they're bringing those problems with us. They're bringing drugs, they're bringing crime, they're rapists and some, I assume are good people, but I speak to border guards and they tell us what we re getting. And it only makes common sense. It only makes common sense. They're sending us not the right people. It's coming from more than Mexico. It's coming from all over South and Latin America, and it's coming probably- probablyfrom the Middle East. But we don't know. Because we have no protection and we have no competence, we don't know what's happening. And it's got to stop and it's got to stop fast." (http://time.com/3923128/donald-trumpannouncement-speech/).

Starting from the first sentence it is an aggressive example of code switching borderlining an attack on Mexico. Donald Trump basically implies that Mexico sends their unwanted people to US to sabotage the neighboring country and relief themselves of the burden of dealing with those people's problems. This implication, with his earlier statement from the same conference becomes even clearer: "The U.S. has become a dumping ground for everybody else's problems." (NYT). Secondly, Trump exaggerates by stating as if it was a fact, that most of the immigrants from Mexico, South America and Middle East are drug addicts and dealers, criminals and rapists, but he assumes that some, only some, are good people. In addition, he says, "it only makes common sense", a strategic idea which aims at dividing the American population into those who are within the mainstream and those who are out of it. Overall, in his first speech during his presidential campaign, Donald Trump had already stated that in his vision of America, immigrants from Mexico, SA and Middle East are unwanted and should be prohibited from entering the US, because they are, according to Trump, criminals, drug dealers and rapists. And, according to Donald Trump's statements from, again, the same conference, they took all the jobs from Americans, and not only them: "That's right. A lot of people up there can't get jobs. They can't get jobs, because there are no jobs, because China has our jobs and Mexico has our jobs. They all have jobs... I'll bring back our jobs from China, from Mexico, from Japan, from so many places. I'll bring back our jobs, and I'll bring back our money." Linguistically simlificated accusation of Chinese, Mexican and Japanese immigrants of "taking" the jobs from American people, and therefore, of greatly raising 
the unemployment rate of America builds xenophobia and racism among the American people - two contagions that America had to spend more than two centuries to almost get rid of.

Speaking of racism, Donald Trump has shown that he doesn't care about African Americans multiple times during his Presidential campaign and after it. His statements about racial inborn laziness of black people said about one his employees: "I think the guy is lazy... And it's probably not his fault because laziness is a trait in blacks. It really is, I believe that. It's not anything they can control". (http://www.ibtimes.com/donald-trumpracism-timeline-breaking-down-presidential-candidatespast-comments-2431421). During his presidential campaign, Donald Trump has been multiple times using his speeches about African Americans to talk about attacks on him on social media and about his family .What's more, when talking about African Americans, Trump mostly talks about how poor, unemployed and uneducated they are. Especially glaring case is his speech on Black History Month and how different it is from Obama's speech on the same matter: "And Paris has done an amazing job in a very hostile CNN community; he's all by himself. Seven people and Paris. I'll take Paris over the seven. But I don't watch CNN, so I don't get to see you as much. I don't like watching fake news. But Fox has treated me very nice, wherever Fox is, thank you"

While Trump mostly does not care about the possible communicative strategy of code switching in order to please the audience and talks about what's important for him, barely touching Black American history and culture, and actually barely talks at all, Obama actually intended to connect with his audience, giving them a spiritual, deep and long speech that is required in the situation, and his ability (or competence) of code switching served him as a useful tool in getting cognitive consonance.

All in all, without the use of sociolinguistic competence and, thus, an ability to code switching, Trump has the same racist approach to black people, as he has to people of all other colors. And that approach is creating a new rupture between white and black people, it is making old wounds of America bleed again. President Donald Trump makes the old mentality of the periods of segregation, of white supremacy gain a foothold in the American identity. His every speech strengthens the white supremacy in the USA and gives the white supremacists more and more power in the society. Donald Trump is not making America Great Again; he is making America degrade into its former racist, unjust, xenophobic self and that is going to bring the US ' people more and more harm that will be harder and harder to heal. American identity from a multiracial, multicultural progressive society is transforming into a society of conservative, uneducated white males.

\section{Conclusion}

It is clear that code switching in Mass Media discourse may be applied as an effective means to get some influence over an addressee intentionally, rarely unintentionally. The issue of code switching is closely connected with the risks of an addressant due to the fact that the perlocutionary effect, and, thus, successfulness of an communication act is difficult to foresee. In many cases a violation of a conventional code is negatively accepted by an addressee, which leads to an unsuccessfulness of communication because an addressee uses his (her) own cognitive and communicative competences.

An intentional and sensible use of code switching is considered to be an additional sociocultural and linguistic competence, a supplementary resource of a communicant, a resource used to reach some pragmatic aims of communication.

It seems clear that, in order for observations about the contextualizing functions of language use to have validity and reliability, they should be based on close observation of discourse. At the same time, it should not be assumed that all elements relevant to discourse and social interaction are visible to the analyst, particularly when the analyst is not embedded in the particular social structures he or she is studying. The optimal approach to understanding these phenomena would thus seem to include ethnic and social explanations. In terms of Mass media analysis code switching which serves to accomplish the projected action of an addressant is difficult to predict as successful, while those that use code switching intuitionally, easier reach the desirable cognito-pragmatic effect basing on their linguistic and sociocultural competences.

\section{References}

1. E.A. Protsenko, Bulletin of the VSU. Series "Linguistics and Intercultural Communication" 1, 123-127 (2014)

2. E. Haugen, Bilingualism in the Americas: A bibliography and research guide. (Montgomery, University of Alabama Press, 1956)

3. C. Nilep, Colorado Research in Linguistic 19, 1-22 (2006)

4. A. Caccamo, Code-switching in conversation. Language, interaction and identity (London: Routledge, 1998)

5. W.E. Williams, Insulting Blacks. 12.09.07 http://townhall.com/columnists/walterewilliams/200 7/09/12/insulting_blacks/page/full.

6. S. Poplack, Codeswitching: Anthropological and Sociolinguistic Perspectives (Berlin: Walter de Gruyter, 1988)

7. C. Myers-Scotton, Language in Society 4(22) 475-503 (1993) 